\title{
A Comparison of the Origin of Idioms in Mandarin and Indonesian
}

\author{
Huang Haiyan, I Dewa Putu Wijana, Tatang Hariri \\ Universitas Gadjah Mada \\ Email: huanghaiyan036@gmail.com
}

\begin{abstract}
In language, idioms can function as stand-alone semantic units because they contain whole concepts. These concepts, formed from human thought, can be explored to discover cultural elements which served as the basis for idiom creation. If the origins of an idiom are known or recognized, that idiom's meaning can be understood more easily. Idioms are frequently used by language communities in their day-to-day lives. However, the origins of idioms in the Indonesian language has almost never been discussed or researched. This article compares the origins of idioms in Mandarin and in Indonesian. It finds that the origins of idioms in Mandarin and in Indonesian are diverse, but in general fit one of two main types: they may be adapted from foreign languages (most importantly in idioms related to religion), or be created within the society and reproduced from generation to generation. Idioms can be traced to either the written tradition or the oral tradition. Idioms in Mandarin generally originate from the written tradition, whereas idioms in Indonesian tend to originate from orality. This study uses the theory of meaning formation first proposed by Ogden and Richards (1911). The comparative method of data analysis is used here, as the origins of idioms in Mandarin and Indonesian are compared.
\end{abstract}

Keywords: idioms, origins, comparative, writing, orality

\section{INTRODUCTION}

Idioms, as a specific form of language, convey extensive cultural information regarding geography, religion, tradition, patterns of thinking, etc. Idioms, as historical artifacts and essential products of culture, offer the potential for a greater understanding of the specific cultures which birthed them. Conversely, a greater understanding of idioms' cultural background offers speakers a greater understanding of the idioms themselves. Idioms also reflect the history of cultural attitudes. For language users, a well-known world or field can serve as a source or reference for the use of idioms. If the origin of a specific idiom is known or recognized, it can assist language users in determining that idiom's meaning.

In all languages, idioms can have broad meanings, particularly when those idioms are transmitted over generations within the same language community. From these idioms, it is possible to understand each language community's culture and lifestyles. Most idioms in Mandarin originate from written tradition; the Great Dictionary of Mandarin Idioms lists approximately 17,000 Mandarin-language idioms which have a traceable history or background. Meanwhile, 
idioms in the Indonesian language tend to be rooted in oral tradition. Idioms in Mandarin generally originate from the culture of the Han Chinese, with vocabulary which has developed over time. Meanwhile, idioms in Indonesian tend to originate from regional cultures and lifestyles, particularly those of the Malays.

Idioms are closely related to meaning formation. As explained by Ogden and Richards (1989:11), meaning formation involves concepts, linguistic symbols, and referents. Symbols represent concepts, and as such there is a direct, causal relationship between the two. Concepts refer to referents, and as such there is a causal relationship between the two. The relationship between symbols and referents, though no less real, is indirect. For a referent and symbol to have meaning, both must pass through the mind (be conceptualized) (Baryadi, 2013:48). Abdul Khak (2011: 144) formulates meaning formation for idioms as follows: $\mathrm{A}+\mathrm{B}$ gives the meaning C. Compound words, meanwhile, he identifies as following the formula $\mathrm{A}+\mathrm{B}$ gives the meaning $\mathrm{AB}$.

In oral/spoken communications, the people of China and Indonesia use idioms to 'refine' their meaning and thus ensure tact in their communications. Idioms are also used for several other reasons, including to ensure linguistic variety, to give advice or teach lessons, to euphemize a negative reality, and to express their respect. Often, without understanding the origin of idioms, one is unable to understand their meanings. In Mandarin, the idiom (1) Shǒuzhu Dàitù （守株待兔） consists of four words: shǒu 'guardian', $z h \bar{u}$ 'plant', dài 'wait', and tù 'rabbit'. As such, if interpreted literally it means 'to stand watch over a tree and await a rabbit'. However, the actual meaning is much different; it instead has the meaning 'to expect results without doing any work'. An understanding of how such a meaning can be derived from this idiom can only be had by examining the origins of the idiom and realizing its deeper connotations. Similarly, the Indonesian idiom (2) semangat empat lima cannot be understood literally; rather, it must be understood in the context of the history of the Indonesian people and their struggle against colonialism. This idiom refers to the proclamation of Indonesian independence in 1945 and the ensuing national revolution.

The goal of this paper is to describe the differences and similarities in the origins of idioms in Mandarin and in Indonesian. Such research is, to the best of the writers' knowledge, almost nonexistent, and the origins of idioms in Indonesian have never been examined using this paper's classification system (i.e. idioms adapted from other languages, idioms created by the language community, idioms based in orality, and idioms based in written tradition). This lack of research into the subject is thus the writers' reason for focusing on the origins of idioms in Mandarin and Indonesian.

The results of this research project are a deeper understanding of idioms. The research results can provide persons with an interest in Mandarin and Indonesian with a sufficient understanding of these languages' idioms to avoid mistakes in language use. Such knowledge can promote, among other things, stronger relations between Indonesia and China.

\section{RESEARCH METHOD}

Regarding the methodology of language and culture research, Mathiot (1964:154-163) writes that a researcher may go in one of two directions. The first is from language to culture, meaning to examine the cultural content of linguistic classes. The second, meanwhile, is from culture to language, meaning to examine the linguistic elements of cultural classes. This research examines the previously hidden cultural background of language, namely the origins of idioms in Mandarin and Indonesian. Because data collected from these two languages differs significantly, the comparative method is also used to explore and compare the sources of idioms in China and in Indonesia.

The comparative method is a basic method for conducting research and obtaining an understanding of specific research objects. This is particularly true in linguistics, where the method has been used for a wealth of studies. Research with different objects requires research which can compare languages. In linguistics, two distinct branches are recognized, namely synchronic linguistics and diachronic linguistics. Comparative linguistics is the branch of linguistics which is intended to use the synchronic 
approach to compare two or more languages (Xu, 2002:1-4). Here, this method is used to compare the origins of idioms in Mandarin and Indonesian.

Research for this article was completed in two stages. The first involved the collection of data (idioms) from the Kamus Idiom Bahasa Indonesia ('Dictionary of Indonesian Idioms', by Abdul Chaer), Kamus Ungkapan Bahasa Indonesia ('Dictionary of Indonesian Sayings', by J. S. Badudu), Kamus Besar Bahasa Indonesia ('Great Dictionary of the Indonesian Language', third edition, by the Language Center Dictionary Writing Team), and the Kamus Besar Idiom Bahasa Mandarin ('Great Dictionary of Mandarin Idioms', second edition, by the Dictionary Writing Team). Although these four dictionaries offered ample data, further data was collected from books and websites, as well as through interviews with Indonesian lecturers and laypersons. The second stage of this research was analyzing the data collected through library research and presenting it in a descriptive-comparative manner.

\section{REVIEW OF THE LITERATURE}

The definition of idioms in Mandarin can be found in the Great Dictionary of Vocabulary, which explains that idioms are idiomatic linguistic units of fixed form which are passed from generation to generation. In general, idioms in Mandarin consist of four words. The meaning of some idioms can be immediately understood from their component words, whereas others can be difficult to understand. Idioms have a fixed, immutable pattern, and as such they function grammatically as single linguistic units. Huang Borong and Liao Xudong (1992:153), in their book Modern Mandarin, write that idioms are particular phrases of fixed form which are passed from generation to generation over many years. Wang Qin (2006: 11-15), in Idiomatics of Mandarin, defines idioms as having four words, a fixed form, and being inherited through tradition.

The definition of idioms in Indonesian, meanwhile, can be seen from the understanding provided by Moeliono (1982:143): idioms are linguistic units which are more than the sum of their parts (i.e. they cannot be divided without losing meaning). Idioms are whole lexical units, and as such any change to them will destroy their meaning; examples include (3) panjang tangan 'long hands', meaning to frequently steal, and (4) rendah hati 'low heart' meaning humble. Chaer (2003:296) identifies idioms as units of speech whose meaning cannot be "predicted" by their components. For instance, (5) menjual gigi 'sell teeth' means to laugh heartily, (6) meja hijau 'green table' means courtroom. Elsewhere, Chaer (2002:74) notes that idioms can take the form of words, phrases, or sentences. Alwi et al. (2003:151, 241) explain that idioms are combinations of two or more words whose meaning cannot immediately be determined based on the component words.

Mandarin-language idioms have been compared with idioms from Thai, Korean, English, Japanese, Russian, and several other languages. There has also been comparison of types of idioms between languages, such as idioms relating to animals, colors, plants, and the human body. For example, "English and Chinese Idioms: A Comparative Study" (Chen Wenbo, 1982) finds that idioms between these two languages may correspond, partially correspond, hardly correspond, or not correspond. Wang Jin'an (2001), in "Analyzing and Comparing Idioms in Mandarin and English", examines idioms from several perspectives, and compares and analyzes their definitions, origins, variations, and functions. Wuling, Yanglan (2007), in "Comparing Idioms in English and Mandarin", compares the definitions and origins of idioms as well as the cultural influence on them, finding that idioms in Mandarin, owing to the language community's different culture, differ significantly from idioms in English. Cai Xinjiao (2011), in "Comparing Idioms in Mandarin and Vietnamese", examines the spread of idioms from China to Vietnam, the integration of these idioms with Vietnamese culture, and the differences between the two cultures which are bridged by idioms. In another article, "A Comparison of Idioms in Mandarin and Indonesian" (2011), Hong Huida used research conducted at Bina Nusantara University to examine education and the situation faced by Indonesian students in learning Mandarin idioms. 


\section{DISCUSSION}

\section{Adaptation of Foreign Idioms}

When two countries or language communities interact, each is certain to adapt, at least partially, the other's language. This may be, for instance, in the form of words, phrases, or sentences. Idioms are frequently found in these phrases and sentences. When foreign idioms enter a language, they change in form and/or sound, but retain the same meaning. As such, idioms from foreign languages are considered to be part of their host languages - in this case, Mandarin and Indonesian. According to Ma Guofan (1978:126-127), adapted idioms differ significantly from loanwords. Loanwords can be adapted directly based on their sounds, meanings, or both, whereas idioms tend to follow one of three processes. In Mandarin, these are 1), to directly take an idiom from a foreign work of literature and then modify it for Mandarin, 2), to take an idiom from a specific linguistic context and adapt it to a Mandarin linguistic context to create a new idiom, $3)$, to simply translate an idiom's meaning. In the history of Mandarin, there are three major events which have influenced the origins of idioms.

After Zhang Qian first opened the Silk Road in the $2^{\text {nd }}$ century $\mathrm{BC}$ (during the Han Dynasty, before $140 \mathrm{BC}$ ), foreign cultures began to enter China. At the time linguistic exchange was generally limited to words; idioms were uncommon. These included, for instance, the word $H u$ (then used to refer to an ethnic minority in northern China) and its derivatives: hú fú (胡服, shift from $\mathrm{Hu}$ ), hú rén (胡人, foreigner), Húluóbo (胡夢卜, carrot), and the idiom (7) Húyán luàn yú (胡言乱语) 'to speak of untrue things'.

Buddhism began to spread in China during the Han Dynasty (147-189 BC) from India. Together with Taoism and Confucianism, it became one of the three most important religions in China. All three had an extensive influence on the Chinese people, and many idioms in Mandarin originated in Buddhism. The book Buddhism with Mandarin Vocabulary contains approximately 300 idioms connected to Buddhism (Liang Xiaohong, 2001:8), including (8) Luòyè Gū̄gēn ( 落叶归根 ) 'fallen leaves return to their tree roots', meaning 'all who roam return to their home villages in old age'; and (9) Wǔtı̌ Tóudì (五体投地) 'pray with the five parts of your body (both hands, both knees, and head) on the ground to show your honor and respect for someone', meaning 'when praying, one must be respectful and honorable ". Another idiom, (10) Niútóu dan Mămiàn (牛头马面), originates from the story about two persons who worked for Yama, the god of death. When someone died, they would bring that person's soul to the afterlife to be judged. There is also the Buddhist story of Niútóu (named A 'bàng before his death), who did not honor his parents. After his death, Yama gave him the head of an ox and the body of a human. This story gave rise to the idiom Niútóuā'bàng, meaning 'brother with the head of an ox'.

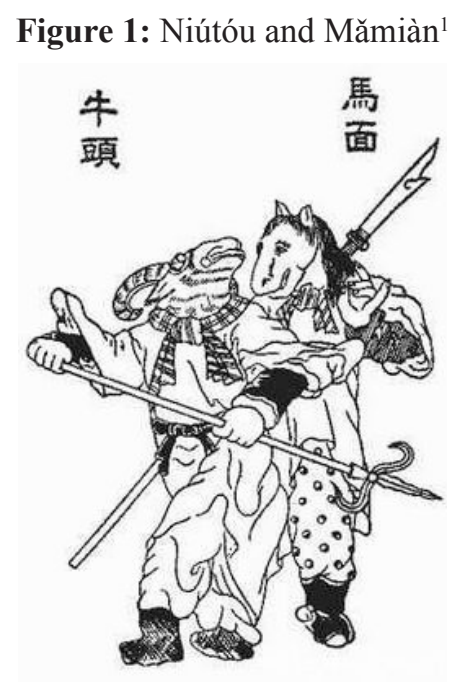

In 1368, when the Ming Dynasty was in power, Western missionaries and merchants began to come to China. During their trade and communications, they brought with them many Western books and words. As the books were translated into Mandarin, the idioms also needed adaptation. However, there are relatively few idioms from Western languages in Mandarin. Examples include (11) Yīshi èrniăo (一石二鸟), which has the same literal and idiomatic meaning as to [to kill] two birds with one stone; (12) Huǒzhōng Qǔlì (火中取栗), which means 'a person unknowingly manipulated by others for a certain purpose' and originates from Jean de La Fontaine's story The Monkey and Cat; and (13) Xiàngyá Zhìtă (象牙之塔), which has the same literal and idiomatic meaning as 'ivory tower': it is used to designate an environment of intellectual 
pursuit disconnected from the practical concerns of everyday life. It comes from the English translation of the Biblical Song of Solomon (7:4). ${ }^{2}$

Numerous idioms in Indonesian are adapted from foreign languages. As Indonesia is a religious country, religion plays an important role in social life. According to the 2010 census, some $87.18 \%$ of Indonesia's population of 237,641,326 are Muslim. A further $6.96 \%$ are Protestant, $2.9 \%$ Catholic, $1.69 \%$ Hindu, $0.72 \%$ Buddhist, $0.05 \%$ Confucian, and $0.13 \%$ practice other religions. ${ }^{3}$ Historically, migration from India, China, Portugal, Arabia, and the Netherlands has played a central role in developing Indonesia's religious and cultural diversity. Hinduism and Buddhism were brought to the Indonesian archipelago between the $2^{\text {nd }}$ and $4^{\text {th }}$ century from India, through Sumatra, Java, and Sulawesi. Islam entered Indonesia in the $14^{\text {th }}$ century through merchants from Gujarat (India), and Protestantism and Catholicism were first brought to the archipelago by the Portuguese, where they were especially influential in Flores and Timor. Together with this migration, many books and stories were translated into Indonesian, thus influencing the wealth of religious idioms. For instance, the idiom (14) kitab suci 'Holy Book' means "God's revelations, in book form". It variously refers to the Qur' an (for Muslims), the Bible (for Christians), the Vedhas (for Hindus), and the Tripitaka (for Buddhists). The idiom (15) hukum karma 'law of karma' means 'a law of causality or retribution for all of a person's doings'. This originates from the Hindu and Buddhist belief that all things on earth are transitory, and whomever does good or evil will receive their due in course. The idiom (16) salat lima waktu 'pray at five times' refers to the mandatory prayers practiced by Muslims (fajr, zuhr, asr, maghrib, and $i s h a$ ). It is used predominantly among Muslims or in relation to Islam.

There are also numerous idioms in Indonesian which were adapted from foreign languages but do not have religious meanings. One of these is (17) bulan madu 'honeymoon', which means 'a retreat for newlyweds to enjoy their marriage' or 'a period of respite in which a couple's love appears able to conquer all'. It is first attested in literature in Anglico Latinum (1552), by Richard Huloet Abece.
The idiom (18) polisi tidur 'sleeping police officer' means a piece of raised asphalt or cement installed on a roadway to slow traffic and can be traced to the British English idiom sleeping policeman. The idioms (19) masuk angin 'be entered by wind' and (20) angin duduk 'sitting wind' originate from Mandarin and refer to a specific ailment commonly treated in traditional Chinese medicine. The idiom (21) menutup mata 'close [one's] eyes' means 'to die'. This euphemism can be to British English and an incident involving the naval officer Horatio Nelson.

\section{Idioms Created by the Chinese and Indonesian Language Communities}

The majority of idioms in Chinese and in Indonesian were created within their respective language communities and passed from generation to generation. As noted above, Mandarin-language idioms tend to consist of four words and originate from written tradition, whereas Indonesianlanguage idioms tend to consist of two words and originate from orality.

According to statistics from Mo Pengling (2001:8) there are more than five hundred Mandarinlanguage idioms from classical Confucian literature (Dàxué (大学), 13; Zhōngyōng (中庸), 21; Lúnyǔ (论语), 173; Mèngzì (孟子), 136; Shījīng (诗 经), 177; Shàngshū (尚书), 104; Lĭjì (礼记), 130; Zhōuyì (周易), 104; and Chünqiū (春秋), 255). Mo records hundreds more from non-Confucian works of literature (Lăozi (老子), 34; Zhuāngzi ( 庄子), 161; and Shì jì (史记) , 266) as well as poetry (Chǔ cí (楚辞), 35; Hàndài shī fù (汉代 诗赋）, 56; Yuèfǔ Gǔshī (乐府古诗), 14; Cáowèi shī fù (曹魏诗赋), 18; Nánběicháo shī fù (南北朝 诗赋), 29; Suídài Shī fù (隋代诗赋), 3; Tángshī ( 唐诗), 310; Wǔdài (五代), 7; Sòngdài Shīci (宋 代诗词), 140; Jīnyuán Shīci, 31; Míngdài Shīcí (明代诗词), 7; and Qīng dài Shīcí (清代诗词), 12). High amount of idioms from classic works of Confucianism, literature, and poetry, indicates that, in periods of prosperity and stability, production of idioms is more common than in periods of war and poverty. For instance, 310 idioms can be traced to the prosperous Tang Dynasty, whereas only 7 can be traced to Wǔdài, which faced extensive conflict over land. 


\section{Idioms from the Written Tradition}

Most idioms in Mandarin originate from the written traditions of the Chinese people themselves. These writings are generally ancient ones, products of history. Dynasties produced varying amounts of idioms, depending on life in each respective dynasty. Dynasties in which there was no war, a stable economy, and prosperity created more idioms than dynasties in opposite situations. One interesting phenomenon is that more idioms were produced in ancient times than in more recent times. These phenomena can also be found in Indonesian.

\section{From Fairy Tales and Fables}

Fairy tales and fables are short stories with lively language which contain moral lessons and philosophical perspectives. They may be ironic, or forbid listeners from doing something. Fairy tales and fables use their simple structures to convey great wisdom in a manner which is easy for readers to accept. One of the wealth of Mandarin-language idioms originating from fairy tales and fables is (22) Bámiáo Zhùzhăng (拔苗 助长), which literally means 'attempt to make a seed grow quickly by pulling it upwards'. It comes from a Spring and Autumn Period (770-476) story about a farmer who, upon seeing that his plant was growing too slowly, pulled on the seedling in attempt to force it to grow. The plant, however, died. As such, this idiom means 'each thing has its own way to succeed'. It reminds listeners that a sense of fear or worry may make them do illogical things, even to their own detriment. The idiom (23) Shǒuzhū Dàitù (守株待兔), meanwhile, literally means 'to stand watch over a tree and await a rabbit'. It originates from a fairy tale set in the Song Dynasty (475-221 BC), in which a man working the fields sees a rabbit run into a tree and die. Afterwards, he refuses to work the fields, instead watching over the tree and awaiting another rabbit. This idiom thus means 'to hope for success without being willing to work hard', as well as 'a person relying on limited experiences knows no flexibility'.

Idioms in Indonesian also originate from fairy tales. For instance, (24) silih-silih kambing 'goat replacement' means 'to borrow something without returning it'. This comes from a fairy tale set in ancient Bali. According to this story, in ancient times dogs had horns, until, one day, a goat asked a dog to lend him his horn; the goat refused to return this horn, and as a result dogs no longer have horns. This metaphor thus clearly refers to persons who borrow something with no intention of returning it. The idiom (25) kambing keras kepala 'stubborn goat', meanwhile, means 'stubborn people refuse to be humble, refuse to surrender'. This idiom comes from a Sundanese story in which two goats approach each other along a steep valley. They both start to walk down a narrow bridge which hangs over a raging river. When they meet in the middle of the bridge, they begin to fight each other with their horns, and as a result both are plunged over into the river below.

\section{From Legends and Myths}

Myths are folktales, in the form of prose, which tell of events believed by the host society to have truly happened in the past and offer an understanding of the natural world and the creatures within it. More generally, the term myth can refer to traditional stories. ${ }^{4}$ Legends and myths are disseminated to convey religious or idealistic experiences and thus shape certain characteristics by serving as a community's teaching material. Myths and legends are also sources for the formation of idioms.

In the Mandarin-language books Shānhăi Jing (山海经), Sōushén Jì (搜神记) and Lièzì (列 子), there are many stories and myths containing idioms. For instance, Kuāfù zhuīrì (夸父追日), which tells of "a man named Kuāfù who chases the sun, hoping to approach it, but ultimately dies of thirst as his club transforms into the forest"-a story of the past, of the desire to understand and conquer nature- has taken the meaning 'to see and do unrealistic things'. (27) Kāitiān Pìdi (开天辟 地), which has the literal meaning "to separate the sky and land", originates from the story of Pangu, the first man ever. When he awoke, after he stood up, the sky was rent asunder from the land and the Earth was created. When he died, his left eye became the sun, and his right eye became the moon. His hair became the stars in the night sky, his voice the wind and clouds, his voice thunder, his body soil, his hands and feet mountains, his blood rivers, 
etc. This idiom is thus used to describe things from the "beginning of time".

In Indonesian, many idioms originate from regional myths or legends. For instance, in Padang there is the legend of Malin Kundang. This legend follows a young man named Malin Kundang who, after becoming wealthy, renounces his mother and is thus turned to stone; this stone is said to be at Air Manis Beach, Padang. Because of this legend, (28) Malin Kundang has taken on the idiomatic meaning of 'ungrateful child'. The people of Indonesia have thus taken the name and used it to refer to all children who do not honor their parents. In a similar veing, the Sundanese legend regarding Tangkuban Perhau Mountain, in which a young man named Sangkuriang attempts to marry his mother, has given rise to the use of the idiom (29) Sangkuriang to refer to men who are attracted to women who are older than them.

\section{From Historical Events}

Historical events and statements by historical figures have given rise to many idioms in both China and in Indonesia. The idiom (30) Căomù Jiēbing (草木皆兵) 'grass and trees, all appear as enemy soldiers' originates from the Battle of Fei River, one of the most famous battles in Chinese military history. During this battle, Chinese soldiers were able to claim victory over an enemy army many times their size. This idiom means 'a terrified person'. The idiom (31) Pòfú Chénzhōu (破釜沉舟) 'to burn one's boats', meanwhile, comes from the story of a hero named Xiangyu. After his military forces crossed an enormous river, he commanded his troops to destroy their vessels and sink their boats to ensure that they would be unwilling to surrender. This idiom thus "always moving forward, never back".

Numerous Indonesian-language idioms originated from Indonesian history. One, (32) hidung belang 'striped nose', meaning 'womanizer', emerged in $17^{\text {th }}$-century Batavia, near the beginning of the Dutch colonial period. The Dutch soldiers lived in the Indonesian archipelago for many years without their wives or other loved ones. In this situation Pieter Corternhoeff, a soldier under Governor General J. P. Coen, became involved in a sex scandal with Saartje Specx. He was found guilty of fornication and imprisoned. Before leaving the courtroom, Coen marked Corterhoeff's nose with charcoal, leaving a black stripe. Since then, the term hidung Belang became used to refer to fornicators and other womanizers. The idiom (33) semangat empat lima 'spirit of forty-five' originates from Indonesia's proclamation of independence in 1945 and refers to the spirits and passion of the nationalist fighters who fought to maintain their newly independent nation. This idiom means 'a burning passion'.

\section{From Works of Literature}

The history of written literature in China can be traced for thousands of years, and as such numerous works have contributed idiomatic sentences or phrases. The numerous Mandarinlanguage idioms originating from written literature include (34) Shuǐluò Shíchu (水落石出) 'water ebbs, rocks seen', which was first used by Shushi, the author of Chibi (赤壁), and means “the situation becomes clear and resolved", (35) Shěshēn Qǔyì ( 舍生取义), which is taken from the sentence 'I want to live, and I want justice, but I must sacrifice for justice’ in Mèngzì. Gàozi (孟子. 告子), has the meaning 'to sacrifice one's life for justice'.

Unlike Mandarin, which draws many idioms from works of literature, in Indonesian only a few idioms are taken from literature. One of these is (36) bukan zaman Sitti Nurbaya 'not the time of Sitti Nurbaya', meaning 'it is no longer the time for arranged marriages'. This idiom is taken from the novel Sitti Nurbaya by Marah Rusli, which tells of a young woman whose arranged marriage ends in tragedy. Most works of literature use idioms which are already found in society. In Langit Kresna Hariadi's novel Gajah Mada (2007), for instance, the idiom (37) pagi buta 'blind morning' in the sentence Ki Buyut Membawa kedua tamunya yang datang di pagi buta itu ke ruang tengah. In Pengakuan Pariyem 'Ki Buyut brought his two guests, who had come in the blind morning, to the center room' means meaning 'very early in the morning when it is still somewhat dark'. In Pengakuan Pariyem, a lyrical novel by Linus Suryadi (2004), the sentence $O$, Allah, jantung hati saya, O Allah, biji mata saya, $O$, anak kembang keluarga. ... 'O God, my heart and soul. O God, seed of my eye, O flower child of the family', three idioms can be identified: (38) 
jantung hati, meaning 'a person who is loved', (39) biji mata, meaning 'dearest, lover', and (40) kembang keluarga, meaning 'the most beloved family member'.

Many other idioms taken from existing oral tradition within each language community can be found in its literature.

\section{From Orality}

Idioms taken from orality (from oral tradition) tend to be phrases, have fixed forms, and originate from the life experiences of ancient cultures. Today, idioms from orality are frequently recorded in written form. While idioms in Mandarin tend to originate from written literature, with only a few idioms originating in orality, idioms in Indonesian tend to originate from orality. As such, it is more difficult to track their origins. Nevertheless, idioms from orality are easily understood and remain influential within their language communities.

Idioms from orality in Mandarin include, for instance, (41) Qìzuľ Bāshé (七嘴八舌) 'seven mouths, eight tongues', which means 'all people attempt to speak in a discussion'; and (42) Méndāng Hùduì (门当户对) 'bound equally heavy, tested equally red', meaning 'see the child, see the inlaw'. This latter idiom draws from Ancient China, where, before a man and a woman could marry, they had to determine whether or not they were of equal social and economic status; if they were not, the family with the higher social and economic status would have difficulty blessing the marriage. There is also the idiom (43) Shùnshǒu Qiānyáng (顺手牵羊) 'as the hand takes the other's goat', meaning 'to steal'; (44) Wángyáng Bǔláo (亡羊 补牢) 'lose the goat, fix the pen', meaning 'in face of trouble, find a way to fix it before it is too late'. Both of these idioms originate from the book Strategies of the Warring States, Chu Dynasty, Vol. IV (Zhànguó Cè. Chǔ Guó, Dì Sì Juăn战国 策. 楚国:第四卷). Idiom (44) originates from the sentences 'When you see a rabbit and release a hound, it is not too late. Likewise, when you lose a goat and fix the pen, it is not too late'.

As stated above, idioms in Indonesian tend to originate from orality and be used by members of the language community in their day-to-day lives. The words used to form idioms tend to be those in common usage; very few uncommon, let alone archaic, words are used. For example, the idiom (45) meja hijau 'green table', meaning 'court of law', is taken from the green tables which are prominently found in Indonesian courtrooms. Green being the color of competition, these green tables signify the courtroom's position as the site where attorneys compete to present facts, theories and arguments. The idiom (46) makan garam 'eat salt', meaning 'experienced', comes from folk wisdom that all people will eat salt; as such, someone who has eaten much salt has experienced much. The idiom (47) cuci tangan 'wash one's hands', meaning 'to not become involved in a mistake' or 'to absolve oneself of a mistake'; because humans do most activities, including mistakes and misdeeds, with their hands, cuci tangan here is understood as to become clean or to absolve oneself of wrongs and thus render oneself beyond reproach.

Some thirty examples can be found of idioms formed using the word ayam 'chicken' in Indonesian. Chicken idioms are particularly common because chickens are living creatures which play an important role in human lives. They are widely used for meat, eggs, feathers, and sport, and as organic 'alarm clocks'. They are easy to raise and feed, and their delicious flesh is enjoyed throughout Indonesia. Owing to the importance of chickens in Indonesian culture, idioms build around chickens can be found in various metaphoric phrases.

First, the chicken as a symbol stands for time. Every morning following sunrise - approximately 5:00 a.m. in Indonesia - chickens will begin to cluck and crow, thus waking any villagers. In the past, before clocks were in wide use, daily routines depended greatly on the sun's patterns; as such, chickens were very important in determining time. This is reflected, for example, in the idioms (48) pagi-pagi ayam 'chicken morning', meaning 'extremely early in the morning', (49) tidur ayam or tidur-tidur ayam 'chicken sleep', meaning 'not sleeping deeply', (50) lena ayam 'chicken rest', meaning 'not sleeping deeply; still sleeping uncomfortably', and (51) hari buta ayam 'blind chicken day', meaning 'evening'.

Second, the symbol of the chicken is often associated with women. This came from the food stalls along the main streets which sell many 
chicken dishes, including fried chicken, chicken congee, and barbecued chicken. On the menu, one can order either a dada 'breast' or paha 'thigh'. Customers thus often say dada yang besar 'big breast' or paha yang besar 'big thigh'. These shops are often open in the evening, towards nightfall, as at other times the locations where these food stalls are set up are used by other businesses or shops. The word ayam has thus become associated with women, including sex workers. This can be seen, for instance, in the idioms (52) ayam kampus 'campus chicken', meaning a female university student who also has sex for money, (53) ayam desa or (54) ayam kampung 'village chicken', both either meaning 'stupid and cowardly' or 'sex worker from a village', and (55) ayam pungguk 'tailless chicken', meaning a woman who cannot bear children.

Third, chickens may symbolize weakness. Because chickens have small bodies, it is easy to catch them and hunt them. Such idioms as (56) mati ayam 'chicken death', meaning to die a pointless death, (57) cakar ayam 'chicken claws', meaning messy handwriting, similar to the tracks of chicken claws, (58) ayam tambatan 'tethered chicken', meaning an aged servant or maid, and (59) buta ayam 'blind chicken', meaning a blind person, have thus emerged.

Fourth, chickens may symbolize bravery or trust. Indonesians often use chickens for competitions; chicken fighting is particularly common. In Java, this is known as sabung ayam 'chicken fighting'. Two roosters fight in an arena until one flees or loses; the losing rooster may even be killed. Such contests often involve betting, which occurs not far from the arena. Sambung ayam, which is also known as berlaga ayam 'chicken competition', can be traced back to the time of the Demak Sultanate. Because of the existence of such competitions, idioms have emerged such as (60) ayam jago 'rooster', meaning a courageous person, (61) merdeka ayam 'chicken freedom', meaning absolute freedom or the ability to do as one pleases, and (62) potong ayam 'cut chicken', meaning to swear an oath.
Figure 2: Origins of Idioms in Mandarin and Indonesian

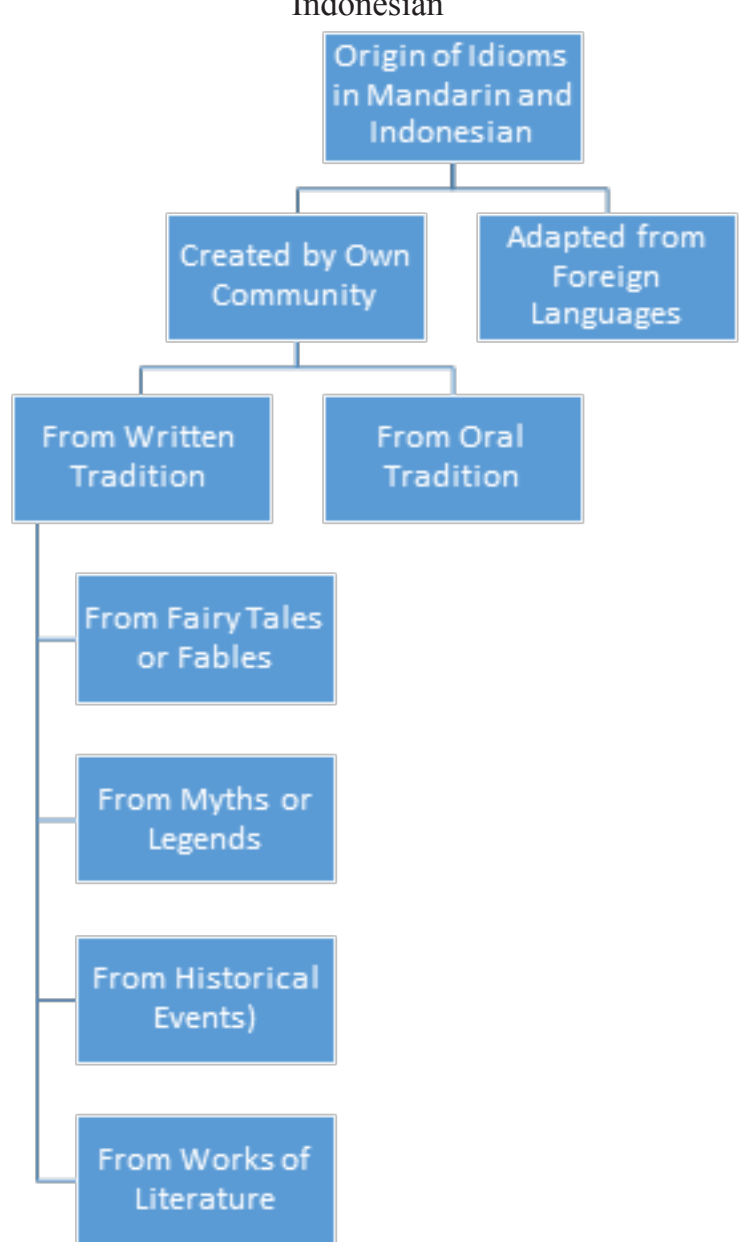

\section{CONCLUSION}

From the above discussion of idioms in Mandarin and Indonesian, it can be concluded that: 1) Idioms in Mandarin and Indonesian can be categorized as idioms adapted from foreign languages and idioms created by the language community itself. The latter category can be further divided into idioms originating from the written tradition of the language community (fairy tales, fables, legends, myths, historical events, and works of literature) and idioms originating from the orality of the language community. 2) There are similarities in the origins of idioms in both languages. First, both languages adapt idioms from foreign languages, particularly in regards to religious idioms. Second, both languages have idioms from written tradition and orality. Third, both languages have idioms which originate from fairy tales, fables, legends, myths, historical events, 
and works of literature. 3) The origins of idioms in Mandarin and Indonesian differ, as idioms in Mandarin tend to originate in written tradition, whereas idioms in Indonesian tend to originate in orality. The proportion of idioms originating from each subcategory of written tradition also differs.

\section{ENDNOTES}

1 http://baike. baidu. com/view/50725. Htm

2 https://en.wikipedia.org/wiki/Ivory_tower

3 "Penduduk Menurut Wilayah dan Agama yang Dianut". Sensus Penduduk 2010. Jakarta, Indonesia: Badan Pusat Statistik. 15 May 2010. Islam 207,176,162 (87.18\%), Protestant 16,528,513 (6.96\%), Catholic 6,907,873 (2.91\%), Hindu 4,012,116 (1.69\%), Buddhist 1,703,254 (0, 72), Confucian 117,091 (0.05\%), other 299,617 (0.13), not answered $139,582(0.06 \%)$, not asked 757,118 $(0.32 \%)$, total $237,641,326$.

4 Kirk, G. S. (1984), "On Defining Myths”, in Alan Dundes, Sacred Narrative: Readings in the Theory of Myth, Berkeley: University of California Press, pp. 53-61

Kirk, G. S. (1973), Myth: Its Meaning and Functions in Ancient and Other Cultures, Berkeley: Cambridge University Press

Simpson, M. (1976), "Introduction. Apollodorus", Gods and Heroes of the Greeks, Amherst: University of Massachusetts Press

\section{REFERENCES}

Abdul Khak, M. (2011). December. Idiom dalam Bahasa Indonesia: Struktur dan Makna. Widyaparwa. Vol. 39. No. 2: 144-154.

Alwi, H., Dardjowidjojo, S., Lapoliwa, H., and Moeliono, A. M. (2003). Tata Bahasa Baku Bahasa Indonesia. Jakarta: Balai Pustaka.

Badudu, J. S. (2009). Kamus Ungkapan Bahasa Indonesia. Jakarta: Kompas.

Baryadi, I. P. (2013). March. Idiom yang Berunsur Kata Kerja dalam Bahasa Indonesia. Sintesis. Vol. 7 No. 1: 46-82.

Cai, X. (2011). A Comparative Study of Vietnamese and Chinese Idiom. Unpublished Dissertation. East China Normal University, Shanghai.

Chaer, A. (1984). Kamus Idiom Bahasa Indonesia. Ende, Flores: Nusa Indah.
(2002). Pengantar Semantik Bahasa Indonesia. Revised edition. Jakarta: Rineka Cipta

(2003). Linguistik Umum. Jakarta: Rineka Cipta.

Chen, W. (1982). English and Chinese Idioms: A Comparative Study. Beijing: Foreigner Language Teach and Research Press.

Dictionary Writing Team. (2011). Kamus Besar Idiom Bahasa Mandarin (second edition). Beijing: Koran Bersinar.

Hong, H. (2011). Comparative Study of ChineseIndonesia Idioms and Teaching Idiom Chinese. Unpublished Tesis. Yunnan University, Yunnan.

Huang, B. \& Liao, X. (1992). Bahasa Mandarin Modern. Beijing: Pendidikan Tinggi.

Language Center Dictionary Writing Team. (2005). Kamus Besar Bahasa Indonesia (third edition). Jakarta: Balai Pustaka.

Liang, X. (2001). Agama Budha dengan Kosakata Mandarin. Taibei: Cahaya Budha.

Ma, G. (1978). Idiom. Huhe Haote: Rakyat Nei Menggu.

Mathiot, M. (1964). Noun Classes and Folk Taxonomy in Papago. American Anthropologist Vol. 64: 340-350.

Mo, P. (2001). Idiom Mandarin dan Budaya Han. Nanjing: Pendidikan Jiangsu.

Moeliono, A. M. (1989). Diksi atau Pilihan Kata. in Kembara Bahasa: Kumpulan Karangan Tersebar. Jakarta: Gramedia.

Suryadi, L. (2004). Pengakuan Pariyem. Yogyakarta: Pustaka Pelajar.

Wang, J. (2001). Menganalisis dan Membangkan Idiom dalam Bahasa Mandarin dan Bahasa Inggris. Journal of Helongjiang College of Education. Vol. 20, No. 1: 81-84.

Wangqing. (2006). Idiomatik dalam Bahasa Mandarin. Shandong: Pendidikan Shandong.

Wuling, Y. (2007). Membanding Idiom dalam Bahasa Mandarin dan Bahasa Inggris. Journal of the Science Education Article Collects Vol. 32: 183-186.

Xu, Y. L. (2002). Contrastive Linguistics. Shanghai: Shanghai Foreign Language Education Press. 